OPEN ACCESS

Edited by:

Kim Stevens,

Royal Veterinary College (RVC),

United Kingdom

Reviewed by:

David Brodbelt,

Royal Veterinary College (RVC),

United Kingdom

Brianna R. Beechler,

Oregon State University, United States

*Correspondence:

Elena Carretón

elena.carreton@ulpgc.es

Specialty section: This article was submitted to Veterinary Epidemiology and Economics,

a section of the journal

Frontiers in Veterinary Science

Received: 21 May 2020

Accepted: 23 September 2020

Published: 22 October 2020

Citation:

Montoya-Alonso JA, Morchón R,

Costa-Rodríguez N, Matos Jl,

Falcón-Cordón Y and Carretón E

(2020) Current Distribution of Selected

Vector-Borne Diseases in Dogs in

Spain. Front. Vet. Sci. 7:564429.

doi: $10.3389 /$ fvets.2020.564429

\title{
Current Distribution of Selected Vector-Borne Diseases in Dogs in Spain
}

\begin{abstract}
José Alberto Montoya-Alonso ${ }^{1}$, Rodrigo Morchón ${ }^{2}$, Noelia Costa-Rodríguez ${ }^{1}$, Jorge Isidoro Matos ${ }^{1}$, Yaiza Falcón-Cordón ${ }^{1}$ and Elena Carretón ${ }^{1 *}$
\end{abstract}

${ }^{1}$ Internal Medicine, Faculty of Veterinary Medicine, Research Institute of Biomedical and Health Sciences (IUIBS), University of Las Palmas de Gran Canaria, Las Palmas de Gran Canaria, Spain, ${ }^{2}$ Animal and Human Dirofilariosis Group, Laboratory of Parasitology, Faculty of Pharmacy, University of Salamanca, Salamanca, Spain

Currently, climate change, modifications of landscapes and habitats due to human activities, as well as an increase in the movement of reservoirs and new species of competent vectors, have contributed to the spread of canine vector-borne diseases. These are mostly emerging and neglected diseases, some of them with zoonotic potential. Therefore, the objective of this study was to assess the prevalence and distribution of four major canine vector-borne diseases (Dirofilaria immitis, Leishmania infantum, Anaplasma spp., and Ehrlichia canis) in Spain. Between September 2018 and February 2020, blood was sampled from 4643 client-owned dogs from 111 veterinary clinics from the 17 autonomous communities of Spain. All samples were tested for the detection of $D$. immitis antigens, and for antibodies against $L$. infantum, Anaplasma spp. and $E$. canis. Of the studied dogs, $22.14 \%$ were positive for one or several diseases while the prevalence was 6.25\% (Cl: 5.59-6.98) for D. immitis, and the seroprevalences were 10.36\% (Cl: 9.52-11.27) for L. infantum, 5.06\% (Cl: 4.47-5.73) for Anaplasma spp., and $4.26 \%$ (Cl: 3.72-4.88) for E. canis. Co-infections by two and three vector-borne diseases were reported in $13 \%$ and $2 \%$ of the infected dogs, respectively. The studied vector-borne diseases are widely distributed throughout the Spanish geography, being observed and expanding northward in the case of $D$. immitis and $L$. infantum. The results point to an insufficiency of preventive measures to avoid the infection, and the need of the implementation of awareness campaigns among veterinarians and owners. Furthermore, a close collaboration between veterinarians, physicians and health authorities would be necessary for such zoonotic vector-borne diseases.

Keywords: Dirofilaria immitis, Leishmania infantum, Anaplasma spp., Ehrlichia canis, epidemiology, seroepidemiology, vector-borne diseases, zoonosis

\section{INTRODUCTION}

It is described that climatic factors (i.e., temperature and humidity) influence the distribution of animal diseases, such as vector-borne diseases, causing dynamic changes in their geographical distribution, epidemiology, pathogenicity, and control. In addition, anthropogenic factors such as globalization with the increasing circulation of people and goods, the transport of infected animals from endemic areas, environmental changes related to human activities and climatic change, favor the spread of vector-borne diseases (1-3). 
Canine vector-borne diseases include a variety of diseases which are mainly transmitted by culicid mosquitoes, phlebotomine sand flies, fleas, and ticks. This research focuses on four canine vector-borne diseases that are among the most clinically relevant and most prevalent in the Spanish geography $(1,3,4)$.

Canine dirofilariosis, caused by Dirofilaria immitis, is a chronic and potentially lethal disease transmitted by culicid mosquitoes (5). In Spain, prediction models based on geoenvironmental features and epidemiological data establish that the highest risk and prevalence occurs in the Canary and Balearic Islands, the southern and eastern peninsular coastal areas and within peninsular areas with irrigated crops and wetlands (1, 68). Canine leishmaniasis is caused by the protozoan Leishmania infantum, and transmitted by the bite of Phlebotomus spp.; the infection can cause a severe clinical presentation which can lead to death or serious systemic repercussions (9-12). In Spain, canine leishmaniasis was considered to be limited to the Mediterranean region $(13,14)$ but currently is considered endemic in most of the Iberian Peninsula and the Balearic Islands with prevalences between 3.7 and $46.6 \%$, being higher in southern and eastern areas of the country (4, 14-18). Both dirofilariosis and leishmaniasis show long asymptomatic periods, which contribute to their spread. Furthermore, lack of preventative measurements and awareness in non-endemic areas may also be contributing to expansion.

Anaplasma spp. and Ehrlichia canis are intracellular gram-negative bacteria, causative agents of infectious cyclic thrombocytopenia (A. platys), granulocytic anaplasmosis ( $A$. phagocytophilum), and monocytic ehrlichiosis (E. canis). These mostly affect dogs and are mainly transmitted by Rhipicephalus sanguineus and Ixodes ricinus $(19,20)$. They cause a disease mainly characterized by mild to severe thrombocytopenia causing bleedings, lethargy, anorexia, fever, lymphadenomegaly, or splenomegaly, in addition to other clinical signs $(3,21,22)$. In Europe, their presence has been reported (3), but in Spain there are few studies reporting these diseases being widely distributed in the northeast, center and southwest of the country, with prevalences between 1 and 20\% (9,23).

Ehrlichia canis is not considered an important zoonotic agent, although some clinical cases have been reported (24). However, Anaplasma spp., D. immitis and L. infantum have an important zoonotic potential (5, 9, 25-27). In humans, D. immitis produces parasitic granulomas in the pulmonary parenchyma, which can be confused with lung cancer (5); $L$. infantum can present two clinical forms: visceral and cutaneous. The cutaneous form can resolve on its own with the formation of scars. However, visceral leishmaniasis is an important zoonotic disease in southern Europe, which can be fatal especially in immunocompromised patients (28). Anaplasma spp. can cause clinical manifestations ranging from mild self-limiting febrile illness, to fatal infections (26).

In Spain, the distribution of these vector borne-diseases is incomplete because epidemiological studies have not been carried out in some provinces and autonomous communities. Moreover, some of these studies were done more than 20 years ago, and in view of the quick spread of vector-borne diseases described in other European countries (29-31), new data should be published to solve this lack of data and present an epidemiological map of their possible expansion that shows a better knowledge of these diseases and allows a more effective fight against them. Therefore, due to the importance and spread of these vector-borne diseases, the objective of this study was to update and complete the epidemiological map of canine $D$. immitis, L. infantum, Anaplasma spp., and E. canis in Spain, estimating prevalences in the Spanish autonomous communities.

\section{MATERIALS AND METHODS \\ Climatic Characteristics of the Study Area}

The Köppen Climate Classification system was applied to identify the different types of climate within Spain $(32,33)$. According to this, temperate climates are the predominant types in the country.

The temperate with dry or hot summer climate (Csa) is the type of climate which covers most of the Iberian Peninsula and the Balearics, occupying $\sim 40 \%$ of its surface. This climate is mainly found in Catalonia, Valencian Community, the Balearic Islands, Andalusia, Castilla La Mancha, Madrid, and Extremadura. This climate is characterized by having hot summers with the average temperature in the warmest month $>22^{\circ} \mathrm{C}$. The temperate with dry or temperate summer climate (Csb) is the second most common climate in Spain, occurring in $\sim 22 \%$ of the territory and is mainly present in Galicia and Castile and León. Like the Csa climate, it has a minimum of rainfall in the summer, but the summer is mild as it does not exceed $22^{\circ} \mathrm{C}$ on average in the warmest month. The third most common climate in Spain is the temperate with a dry season and temperate summer climate $(\mathrm{Cfb})$. It is located in the northern region and mainly presented in Asturias, Cantabria, Basque Country, La Rioja, Navarra, and Aragón. Murcia is mainly represented by the cold steppe climate (Bsk); this correspond to a dry climate which is characterized as such because the evaporation exceeds precipitation on average, but is less than potential evaporation; average temperature is $<18^{\circ} \mathrm{C}$. Finally, the Canary Islands present different climates but, overall, the climate is subtropical and desert, moderated by the sea and in summer by the trade winds (Subtr).

\section{Sample Collection and Analysis}

The study included a total of 4,643 blood samples from domestic dogs, collected between September 2018 and February 2020. Samples were collected from dogs presented for routine health examination to 111 veterinary clinics and hospitals located in the 17 autonomous communities present in Spain (Figure 1 and Table 1); practices were asked to choose the samples at 'random'. The participation of clinics and hospitals was voluntary and samples were collected during the period of time in which the study lasted. The criteria for inclusion were no having previous history of infection by the studied vector-borne diseases, not receiving regular chemoprophylaxis for the studied vectorborne diseases, and owner consent to participate in the survey. Epidemiological data, such as gender, age at presentation to the 


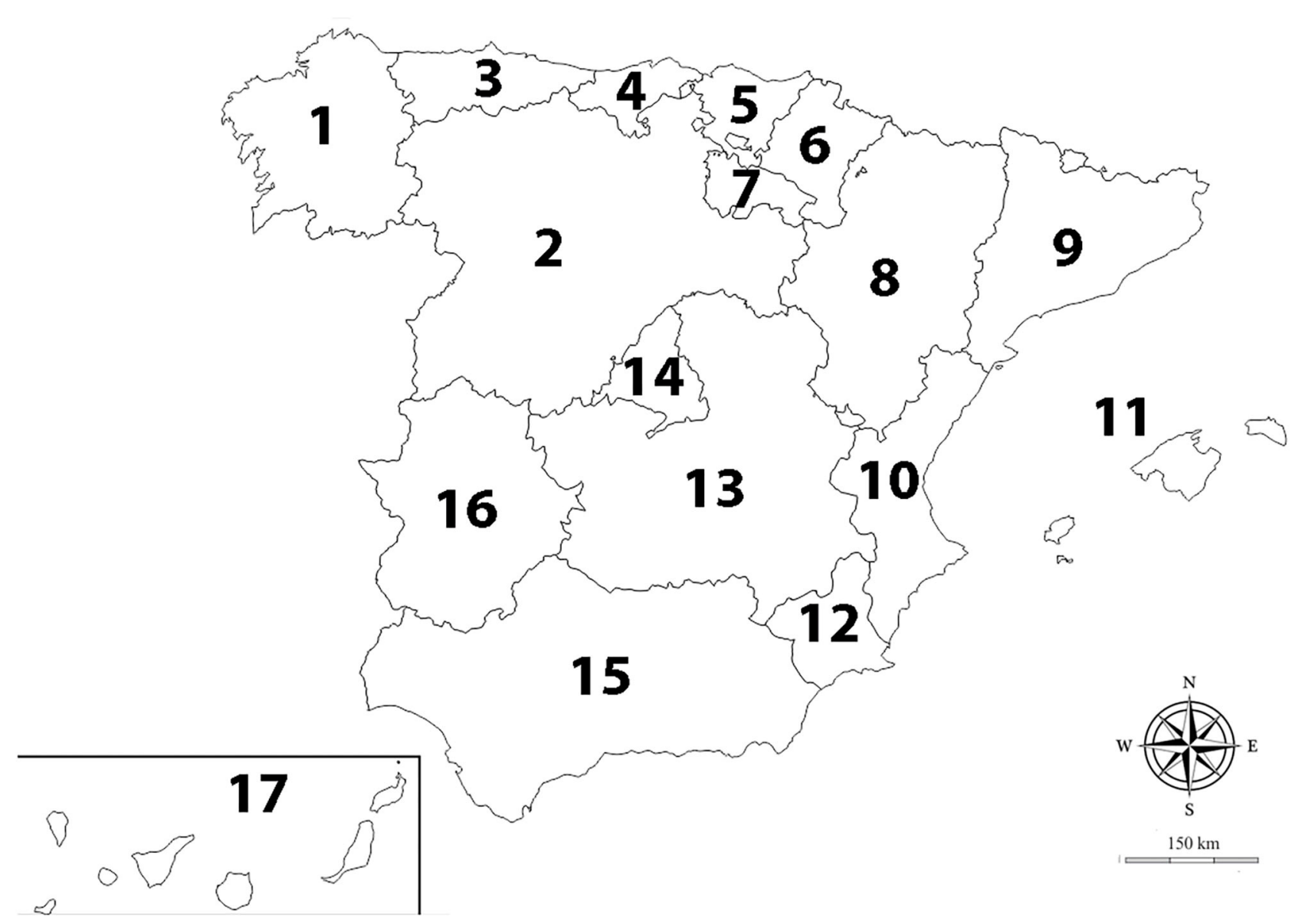

FIGURE 1 | Autonomous communities of Spain. (1) Galicia; (2) Castile and Leon; (3) Asturias; (4) Cantabria; (5) Basque Country; (6) Navarra; (7) La Rioja; (8) Aragon; (9) Catalonia; (10) Valencian Community; (11) Balearic Islands; (12) Murcia; (13) Castilla-La Mancha; (14) Madrid; (15) Andalusia; (16) Extremadura; (17) Canary Islands.

clinics and habitat (where the dog spends all or most of its time: indoor, outdoor, or both), were recorded.

Blood samples were collected from the cephalic or jugular vein, placed in $3 \mathrm{ml}$ serum tubes and centrifuged. Serum samples were kept at $-20^{\circ} \mathrm{C}$ until tests were performed. All samples were tested for the detection of $D$. immitis antigens and for the detection of antibodies against L. infantum, E. canis, and Anaplasma spp. following immunochromatography techniques by using Uranotest Quattro (Uranovet, Barcelona Spain) following manufacturer's instructions. Briefly, one drop of serum or plasma was added along with two drops of reagent to each of the test strips. The sensitivity of the tests was: $97 \%$ for L. infantum (vs. IFI), 95\% for Ehrlichia (vs. IFI), 94\% for D. immitis (vs. necropsy) and $96 \%$ for Anaplasma (vs. IFI). The specificity was: $99 \%$ for L. infantum (vs. IFI), $94.6 \%$ for Ehrlichia (vs. IFI), 100\% for D. immitis (vs. necropsy), and $99 \%$ for Anaplasma (vs. IFI).

\section{Statistical Analysis}

Data were analyzed using SPSS Base 20.0 software (SPSS Inc./IBM, Chicago, Illinois, USA). Descriptive analysis of the qualitative variables was carried out considering the number of cases and percentages. Univariate and multivariate logistic regression models were carried out to establish the degree of association between the variables gender, age, presence of co-infection, climate, habitat, region and the presence of Dirofilaria, Leishmania, Anaplasma, and Ehrlichia. Each variable was analyzed individually by obtaining crude odds ratios (ORs) and their 95\% confidence intervals. Subsequently, the OR values adjusted for the rest of the factors, using logistic regressions, and their corresponding $95 \%$ confidence intervals were estimated as well.

\section{RESULTS}

Of the studied dogs, $54.3 \%(2,521 / 4,643)$ were male and $45.7 \%$ $(2,122 / 4,643)$ were female. The age ranged from 2 months to 19 years old, and dogs were further divided into four age groups: dogs $<1$ year $(4.6 \%$; 214/4,643), from 1 to 5 years $(36.1 \%$; $1676 / 4,643)$, from 5 to 10 years $(37.6 \% ; 1,742 / 4,643)$, from 10 to 15 years $(19.9 \%$; 926/4,643), and dogs >15 years $(1.8 \%$; $85 / 4,643)$. Regarding habitat, $30 \%(1,393 / 4,643)$ of the dogs were 
TABLE 1 | Prevalence and seroprevalences of the studied vector-borne diseases in each autonomous community in Spain.

\begin{tabular}{|c|c|c|c|c|c|c|c|c|c|c|c|c|}
\hline & Regions & Climate & Veterinary centers & $n$ & + D. immitis & $\%$ & + L. infantum & $\%$ & + Anasplama spp. & $\%$ & + E. canis & $\%$ \\
\hline 1 & Galicia & Csb & 6 & 330 & 21 & 6.36 & 15 & 4.55 & 10 & 3.03 & 8 & 2.42 \\
\hline 2 & Castile and Leon & Csb & 8 & 401 & 25 & 6.23 & 23 & 5.74 & 11 & 2.74 & 8 & 2.00 \\
\hline 3 & Asturias & $\mathrm{Cfb}$ & 3 & 116 & 1 & 0.86 & 1 & 0.86 & 2 & 1.72 & 5 & 4.31 \\
\hline 4 & Cantabria & Cfb & 4 & 147 & 2 & 1.36 & 3 & 2.04 & 7 & 4.76 & 6 & 4.08 \\
\hline 5 & Basque Country & $\mathrm{Cfb}$ & 6 & 104 & 0 & 0.00 & 2 & 1.92 & 3 & 2.88 & 5 & 4.81 \\
\hline 6 & Navarra & $\mathrm{Cfb}$ & 3 & 107 & 2 & 1.87 & 7 & 6.54 & 3 & 2.80 & 6 & 5.61 \\
\hline 7 & La Rioja & $\mathrm{Cfb}$ & 4 & 121 & 8 & 6.61 & 8 & 6.61 & 3 & 2.48 & 5 & 4.13 \\
\hline 8 & Aragon & Cfb & 6 & 131 & 10 & 7.63 & 21 & 16.03 & 15 & 11.45 & 9 & 6.87 \\
\hline 9 & Catalonia & Csa & 10 & 510 & 39 & 7.65 & 69 & 13.53 & 16 & 3.14 & 21 & 4.12 \\
\hline 10 & Valencian Community & Csa & 5 & 374 & 26 & 6.95 & 64 & 17.11 & 26 & 6.95 & 34 & 9.09 \\
\hline 11 & Balearic Islands & Csa & 8 & 180 & 11 & 6.11 & 38 & 21.11 & 9 & 5.00 & 6 & 3.33 \\
\hline 12 & Murcia & Bsk & 2 & 223 & 18 & 8.07 & 55 & 24.66 & 22 & 9.87 & 11 & 4.93 \\
\hline 13 & Castilla-La Mancha & Csa & 8 & 237 & 9 & 3.80 & 17 & 7.17 & 9 & 3.80 & 12 & 5.06 \\
\hline 14 & Madrid & Csa & 10 & 461 & 15 & 3.25 & 38 & 8.24 & 16 & 3.47 & 21 & 4.56 \\
\hline 15 & Andalusia & Csa & 11 & 427 & 29 & 6.79 & 77 & 18.03 & 38 & 8.90 & 25 & 5.85 \\
\hline 16 & Extremadura & Csa & 5 & 202 & 17 & 8.42 & 29 & 14.36 & 16 & 7.92 & 5 & 2.48 \\
\hline \multirow[t]{2}{*}{17} & Canary Islands & Subtr & 12 & 572 & 57 & 9.97 & 14 & 2.45 & 29 & 5.07 & 11 & 1.92 \\
\hline & Total & & 111 & 4,643 & 290 & 6.25 & 481 & 10.36 & 235 & 5.06 & 198 & 4.26 \\
\hline
\end{tabular}

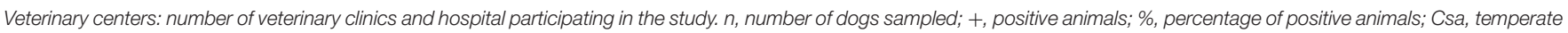

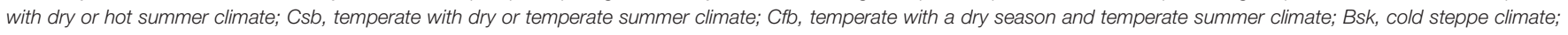
Subtr, subtropical.

indoor (dogs always kept inside the house), 37.2\% (1,726/4,643) were outdoor (those always kept outside the house) and $32.8 \%$ $(1,524 / 4,643)$ for dogs that spent at least $1-50 \%$ of their time outdoors (indoor/outdoor).

The results showed that $22.14 \%(1,028 / 4,643)$ were positive for one or several diseases. The overall prevalence of $D$. immitis was $6.25 \%(290 / 4,643)$ (95\% CI: 5.59-6.98) and the seroprevalences of L. infantum, Anaplasma spp., and E. canis were $10.36 \%$ (481/4,643) (95\% CI: 9.52-11.27), 5.06\% (235/4,643) (95\% CI: 4.47-5.73) and 4.26\% (198/4,643) (95\% CI: 3.72-4.88), respectively. Results by autonomous communities are shown in Figure 2 and Table 1, while results by gender, groups of age and habitat are shown in Table 2.

Taking into account the sensitivity and specificity of the tests used, true prevalence could be estimated as 6.65\% ( $D$. immitis), $10.78 \%$ (L. infantum), 5.32\% (Anaplasma spp.), and $4.69 \%$ (E. canis).

Co-infections were observed in $15 \%$ of the infected dogs. Of them, $13 \%$ were infected by two vector-borne infections, being L. infantum + E. canis $(\mathrm{n}=41)$, L. infantum +Anaplasma spp. $(n=32)$, L. infantum $+D$. immitis $(n=19)$, D. immitis + Anaplasma spp. $(n=19)$, E. canis + Anaplasma spp. $(n=$ $17)$, D. immitis + E. canis $(n=6)$. Furthermore, $2 \%$ of them were co-infected by three vector-borne infections (E. canis $+L$. infantum + Anaplasma spp., $n=13$; D. immitis + E. canis + L. infantum, $n=8$ ).

By climates, D. immitis and L. infantum trended to show lower prevalences in the autonomous communities dominated by the $\mathrm{Cfb}$ climate; while higher prevalences were observed in the Canary Islands (D. immitis), and Csa and Bsk climates
(L. infantum). Anaplasma spp. and E. canis were quite homogeneously distributed in the country.

Gender and age were significantly associated with the presence of $D$. immitis, being females $43 \%$ more likely to present dirofilariosis. No significant association was observed between gender and the presence of Leishmania, Anaplasma and Ehrlichia (Table 3).

Regarding age, a significant association was observed with the presence of Leishmania; as age increased, the risk of leishmaniasis increased, except in dogs $>15$ years, in which the association was no longer significant. In dogs infected by Anaplasma spp., only the group of 10-15 years presented a significant association, being the risk of presenting infection 2.93 times higher than in dogs $<1$ year. When dogs infected by E. canis were analyzed, those between 5 and 10 years showed 3.37 times more risk of presenting the infection, and those between 10 and 15 years showed 3.86 times more risk of infection, when compared to dogs $<1$ years, both associations being significant. The rest of the age groups studied did not show any significant association with the presence of E. canis.

The risk of infection by $D$. immitis was significantly higher in dogs >1 year; also, co-infection with Anaplasma spp. significantly increased the risk of being infected by $D$. immitis by $64 \%$. The indoor/outdoor or outdoor habitat was significantly associated with the presence of dirofilariosis, while the $\mathrm{Cfb}$ climate compared to the Bsk climate reduced the presence of dirofilariosis by $66 \%$.

Co-infections with Anaplasma spp. and E. canis significantly increased the risk of L. leishmaniasis by 79 and $56 \%$, respectively. Indoor/outdoor or outdoor habitat was significantly associated 
A

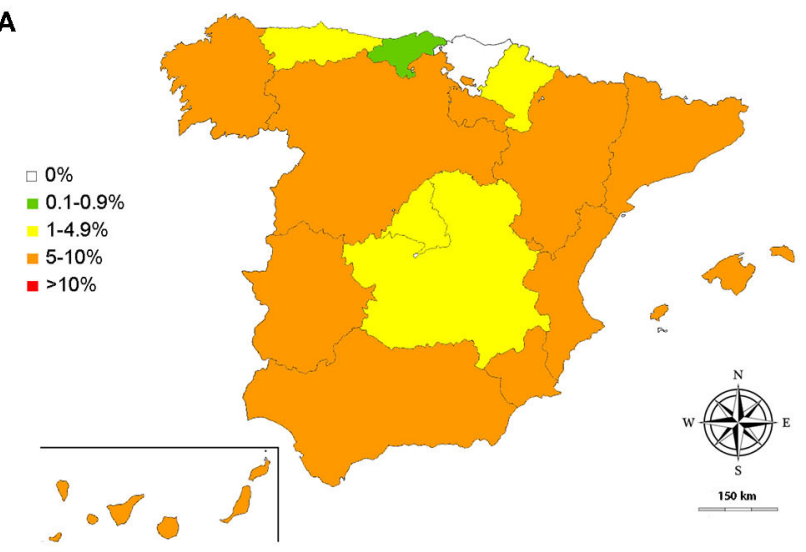

C

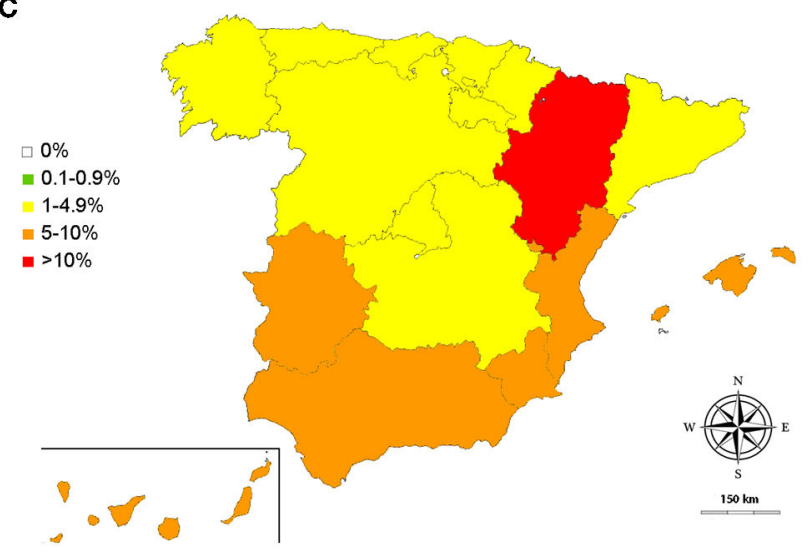

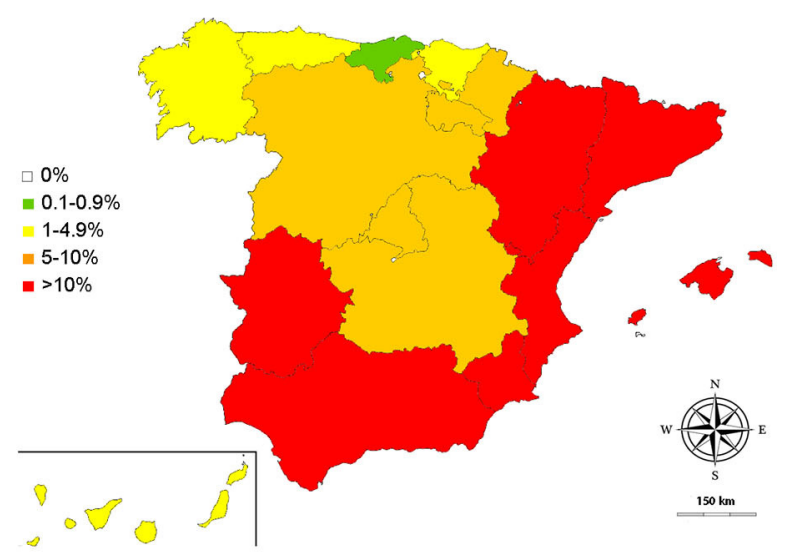

D

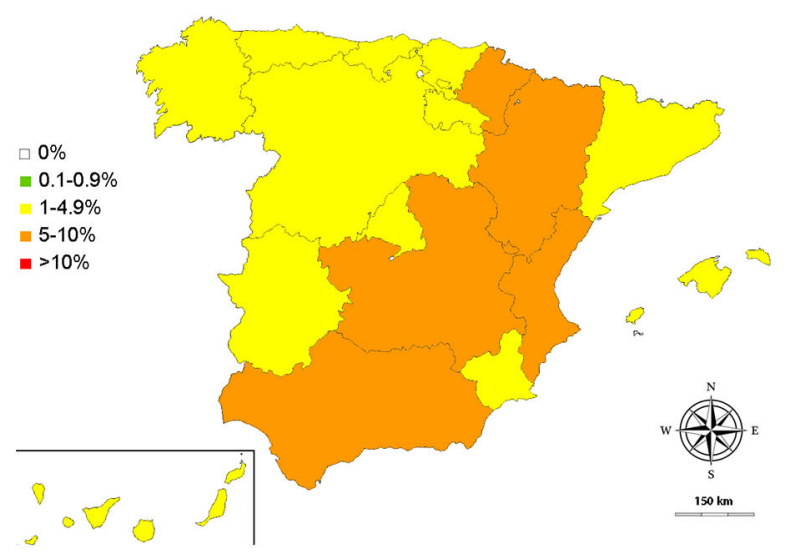

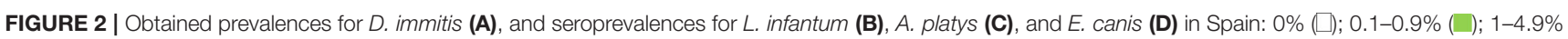
( ); 5-10\% (口); >10 (口).

TABLE 2 | Prevalence and seroprevalences of vector-borne diseases studied by gender, age, and habitat.

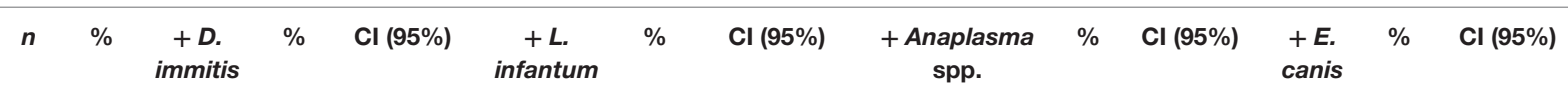

\begin{tabular}{|c|c|c|c|c|c|c|c|c|c|c|c|c|c|c|}
\hline \multicolumn{15}{|l|}{ Gender } \\
\hline Male & 2,521 & 54.3 & 138 & 5.47 & $(4.65,6.43)$ & 271 & 10.75 & $(9.60,12.02)$ & 129 & 5.12 & $(4.32,6.05)$ & 97 & 3.85 & $(3.16,4.67)$ \\
\hline Female & 2,122 & 45.7 & 152 & 7.16 & $(6.14,8.34)$ & 210 & 9.90 & $(8.70,11.24)$ & 106 & 4.99 & $(4.15,6.01)$ & 101 & 4.76 & $(3.93,5.75)$ \\
\hline \multicolumn{15}{|l|}{ Age } \\
\hline$<1$ year & 214 & 4.6 & 5 & 2.34 & $(1.00,5.35)$ & 14 & 6.54 & $(3.94,10.68)$ & 6 & 2.80 & $(1.29,5.98)$ & 2 & 0.93 & $(0.26,3.34)$ \\
\hline $1-5$ years & 1,676 & 36.1 & 107 & 6.38 & $(5.31,7.66)$ & 179 & 10.68 & $(9.29,12.25)$ & 75 & 4.47 & $(3.58,5.57)$ & 66 & 3.94 & $(3.11,4.98)$ \\
\hline $5-10$ years & 1,742 & 37.6 & 114 & 6.54 & $(5.48,7.80)$ & 194 & 11.14 & $(9.74,12.70)$ & 80 & 4.59 & $(3.71,5.68)$ & 73 & 4.19 & $(3.35,5.24)$ \\
\hline 10-15 years & 926 & 19.9 & 60 & 6.48 & $(5.07,8.25)$ & 87 & 9.39 & $(7.68,11.45)$ & 73 & 7.88 & $(6.32,9.80)$ & 45 & 4.86 & $(3.65,6.44)$ \\
\hline$>15$ years & 85 & 1.8 & 4 & 4.71 & $(1.85,11.48)$ & 7 & 8.23 & $(4.05,16.04)$ & 1 & 1.18 & $(0.21,6.37)$ & 5 & 5.88 & $(2.54,13.04)$ \\
\hline \multicolumn{15}{|l|}{ Habitat } \\
\hline Indoor & 1,393 & 30 & 25 & 1.79 & $(1.22,2.64)$ & 59 & 4.23 & $(3.30,5.42)$ & 14 & 1.00 & $(0.60,1.68)$ & 10 & 0.72 & $(0.39,1.32)$ \\
\hline Outdoor & 1,726 & 37.2 & 158 & 9.15 & $(7.88,10.61)$ & 269 & 15.59 & $(13.95,17.37)$ & 130 & 7.53 & $(6.38,8.87)$ & 92 & 5.33 & $(4.37,6.49)$ \\
\hline Indoor/Outdoor & 1,524 & 32.8 & 107 & 7.02 & $(5.84,8.41)$ & 153 & 9.91 & $(8.63,11.65)$ & 91 & 5.97 & $(4.89,7.28)$ & 96 & 6.30 & $(5.19,7.63)$ \\
\hline Total & 4,643 & & 290 & 6.25 & $(5.59,6.98)$ & 481 & 10.36 & $(9.52,11.27)$ & 235 & 5.06 & $(4.47,5.73)$ & 198 & 4.26 & $(3.72,4.88)$ \\
\hline
\end{tabular}

n, number of dogs sampled; +, positive animals; \%, percentage of positive animals. 
TABLE 3 | Factors associated with the presence of D. immitis, L. infantum, Anaplasma spp., and E. canis.

\begin{tabular}{|c|c|c|c|c|c|c|c|c|}
\hline \multirow[t]{2}{*}{ Variables } & \multicolumn{2}{|c|}{ D. immitis } & \multicolumn{2}{|c|}{ L. infantum } & \multicolumn{2}{|c|}{ Anaplasma spp. } & \multicolumn{2}{|c|}{ E. canis } \\
\hline & $\begin{array}{l}\text { Crude ORs } \\
\text { (CI 95\%) }\end{array}$ & $\begin{array}{l}\text { Adjusted ORs } \\
\text { (IC 95\%) }\end{array}$ & $\begin{array}{l}\text { Crude ORs } \\
\text { (Cl 95\%) }\end{array}$ & $\begin{array}{l}\text { Adjusted ORs } \\
\text { (IC 95\%) }\end{array}$ & $\begin{array}{l}\text { Crude ORs } \\
\text { (Cl 95\%) }\end{array}$ & $\begin{array}{l}\text { Adjusted ORs } \\
\text { (IC 95\%) }\end{array}$ & $\begin{array}{l}\text { Crude ORs } \\
\text { (Cl 95\%) }\end{array}$ & $\begin{array}{l}\text { Adjusted ORs } \\
\text { (IC 95\%) }\end{array}$ \\
\hline Gender ${ }^{\#}$ & $\begin{array}{l}1.33 \\
(1.05-1.69)^{\star}\end{array}$ & $\begin{array}{l}1.43 \\
(1.12-1.82)^{\star}\end{array}$ & $\begin{array}{l}1.43 \\
(1.12-1.82)\end{array}$ & $\begin{array}{l}0.96 \\
(0.79-1.18)\end{array}$ & $\begin{array}{l}0.97 \\
(0.74-1.26)\end{array}$ & $\begin{array}{l}0.99 \\
(0.75-1.31)\end{array}$ & $\begin{array}{l}1.24 \\
(0.93-1.66)\end{array}$ & $\begin{array}{l}1.33 \\
(0.99-1.78)\end{array}$ \\
\hline \multicolumn{9}{|l|}{ Age } \\
\hline$<1$ year & Ref. & Ref. & Ref. & Ref. & Ref. & Ref. & Ref. & Ref. \\
\hline $1-5$ years & $\begin{array}{l}2.85 \\
(1.14-7.07)^{*}\end{array}$ & $\begin{array}{l}3.03 \\
(1.21-7.59)^{\star}\end{array}$ & $\begin{array}{l}1.70 \\
(0.97-3.00)\end{array}$ & $\begin{array}{l}2.07 \\
(1.16-3.69)^{\star}\end{array}$ & $\begin{array}{l}1.62 \\
(0.69-3.77)\end{array}$ & $\begin{array}{l}1.47 \\
(0.62-3.46)\end{array}$ & $\begin{array}{l}2.97 \\
(0.92-9.53)\end{array}$ & $\begin{array}{l}3.05 \\
(0.94-9.86)\end{array}$ \\
\hline 5-10 years & $\begin{array}{l}2.92 \\
(1.18-7.25)^{\star}\end{array}$ & $\begin{array}{l}3.38 \\
(1.35-8.43)^{\star}\end{array}$ & $\begin{array}{l}1.79 \\
(1.02-3.14)^{\star}\end{array}$ & $\begin{array}{l}2.27 \\
(1.28-4.05)^{\star}\end{array}$ & $\begin{array}{l}1.66 \\
(0.71-3.87)\end{array}$ & $\begin{array}{l}1.67 \\
(0.71-3.93)\end{array}$ & $\begin{array}{l}3.16 \\
(0.98-10.12)\end{array}$ & $\begin{array}{l}3.37 \\
(1.04-10.87)^{\star}\end{array}$ \\
\hline $10-15$ years & $\begin{array}{l}2.89 \\
(1.14-7.30)^{\star}\end{array}$ & $\begin{array}{l}3.10 \\
(1.21-7.88)^{\star}\end{array}$ & $\begin{array}{l}1.48 \\
(0.82-2.65)\end{array}$ & $\begin{array}{l}1.62 \\
(0.88-2.95)\end{array}$ & $\begin{array}{l}2.92 \\
(1.25-6.81)^{\star}\end{array}$ & $\begin{array}{l}2.93 \\
(1.24-6.93)^{\star}\end{array}$ & $\begin{array}{l}3.76 \\
(1.15-12.19)^{\star}\end{array}$ & $\begin{array}{l}3.86 \\
(1.17-12.66)^{\star}\end{array}$ \\
\hline$>15$ years & $\begin{array}{l}2.06 \\
(0.541-7.8)\end{array}$ & $\begin{array}{l}2.21 \\
(0.57-8.57)\end{array}$ & $\begin{array}{l}1.28 \\
(0.49-3.29)\end{array}$ & $\begin{array}{l}1.09 \\
(0.41-2.91)\end{array}$ & $\begin{array}{l}0.83 \\
(0.16-4.22)\end{array}$ & $\begin{array}{l}0.58 \\
(0.11-3.05)\end{array}$ & $\begin{array}{l}4.39 \\
(1.02-18.82)^{\star}\end{array}$ & $\begin{array}{l}4.21 \\
(0.97-18.24)\end{array}$ \\
\hline \multicolumn{9}{|l|}{ Co-infection } \\
\hline D. immitis & - & - & $\begin{array}{l}1.60 \\
(1.14-2.24)^{\star}\end{array}$ & $\begin{array}{l}1.26 \\
(0.88-1.79)\end{array}$ & $\begin{array}{l}2.23 \\
(1.48-3.36)^{\neq}\end{array}$ & $\begin{array}{l}1.57 \\
(1.01-2.41)^{\star}\end{array}$ & $\begin{array}{l}1.53 \\
(0.93-2.52)\end{array}$ & $\begin{array}{l}1.14 \\
(0.68-1.91)\end{array}$ \\
\hline L. infantum & $\begin{array}{l}1.60 \\
(1.14-2.24)^{\star}\end{array}$ & $\begin{array}{l}1.25 \\
(0.87-1.78)\end{array}$ & - & - & $\begin{array}{l}2.63 \\
(1.90-3.64)^{\neq}\end{array}$ & $\begin{array}{l}1.82 \\
(1.29-2.57)^{\star}\end{array}$ & $\begin{array}{l}2.29 \\
(1.60-3.29)^{\neq}\end{array}$ & $\begin{array}{l}1.59 \\
(1.09-2.31)^{\star}\end{array}$ \\
\hline Anaplasma spp. & $\begin{array}{l}2.23 \\
(1.48-3.36)^{\neq}\end{array}$ & $\begin{array}{l}1.64 \\
(1.07-2.50)^{\star}\end{array}$ & $\begin{array}{l}2.63 \\
(1.90-3.64)^{\neq}\end{array}$ & $\begin{array}{l}1.79 \\
(1.26-2.53)^{\star}\end{array}$ & - & - & $\begin{array}{l}3.85 \\
(2.56-5.80)^{\neq}\end{array}$ & $\begin{array}{l}2.65 \\
(1.73-4.05)^{\neq}\end{array}$ \\
\hline E. canis & $\begin{array}{l}1.53 \\
(0.93-2.52)\end{array}$ & $\begin{array}{l}1.13 \\
(0.67-1.89)\end{array}$ & $\begin{array}{l}2.29 \\
(1.60-3.29)^{\neq}\end{array}$ & $\begin{array}{l}1.56 \\
(1.07-2.29)^{\star}\end{array}$ & $\begin{array}{l}3.85 \\
(2.56-5.80)^{\neq}\end{array}$ & $\begin{array}{l}2.62 \\
(1.71-4.01)^{\neq}\end{array}$ & - & - \\
\hline \multicolumn{9}{|l|}{ Climate } \\
\hline Bsk & Ref. & Ref. & Ref. & Ref. & Ref. & Ref. & Ref. & Ref. \\
\hline $\mathrm{Cfb}$ & $\begin{array}{l}0.37 \\
(0.19-0.70)^{\star}\end{array}$ & $\begin{array}{l}0.34 \\
(0.14-0.77)^{\star}\end{array}$ & $\begin{array}{l}0.18 \\
(0.12-0.29)^{\neq}\end{array}$ & $\begin{array}{l}0.27 \\
(0.15-0.48)^{\neq}\end{array}$ & $\begin{array}{l}0.43 \\
(0.24-0.76)^{\star}\end{array}$ & $\begin{array}{l}1.91 \\
(0.82-4.47)\end{array}$ & $\begin{array}{l}1.00 \\
(0.50-2.01)\end{array}$ & $\begin{array}{l}1.62 \\
(0.63-4.14)\end{array}$ \\
\hline Csa & $\begin{array}{l}0.74 \\
(0.44-1.23)\end{array}$ & $\begin{array}{l}0.91 \\
(0.49-1.70)\end{array}$ & $\begin{array}{l}0.49 \\
(0.35-0.68)^{\neq}\end{array}$ & $\begin{array}{l}0.74 \\
(0.49-1.11)\end{array}$ & $\begin{array}{l}0.52 \\
(0.32-0.84)^{\star}\end{array}$ & $\begin{array}{l}1.04 \\
(0.59-1.85)\end{array}$ & $\begin{array}{l}1.05 \\
(0.56-1.98)\end{array}$ & $\begin{array}{l}1.35 \\
(0.64-2.84)\end{array}$ \\
\hline Csb & $\begin{array}{l}0.76 \\
(0.43-1.34)\end{array}$ & $\begin{array}{l}0.75 \\
(0.35-1.64)\end{array}$ & $\begin{array}{l}0.16 \\
(0.10-0.26)^{\neq}\end{array}$ & $\begin{array}{l}0.25 \\
(0.14-0.45)^{\neq}\end{array}$ & $\begin{array}{l}0.27 \\
(0.14-0.50)^{\neq}\end{array}$ & $\begin{array}{l}1.12 \\
(0.46-2.73)\end{array}$ & $\begin{array}{l}0.43 \\
(0.19-0.94)^{*}\end{array}$ & $\begin{array}{l}0.80 \\
(0.29-2.20)\end{array}$ \\
\hline Subtr & $\begin{array}{l}1.26 \\
(0.72-2.19)\end{array}$ & $\begin{array}{l}1.54 \\
(0.87-2.75)\end{array}$ & $\begin{array}{l}0.07 \\
(0.04-0.14)^{\ddagger}\end{array}$ & $\begin{array}{l}0.08 \\
(0.04-0.15)^{\ddagger}\end{array}$ & $\begin{array}{l}0.48 \\
(0.27-0.86)^{\star}\end{array}$ & $\begin{array}{l}0.69 \\
(0.37-1.26)\end{array}$ & $\begin{array}{l}0.37 \\
(0.16-0.88)^{*}\end{array}$ & $\begin{array}{l}0.47 \\
(0.19-1.12)\end{array}$ \\
\hline \multicolumn{9}{|l|}{ Habitat } \\
\hline Indoors & Ref. & Ref. & Ref. & Ref. & Ref. & Ref. & Ref. & Ref. \\
\hline Indoors/Outdoors & $\begin{array}{l}4.13 \\
(2.65-6.42)^{\neq}\end{array}$ & $\begin{array}{l}4.14 \\
(2.65-6.48)^{\neq}\end{array}$ & $\begin{array}{l}2.52 \\
(1.85-3.43)^{\neq}\end{array}$ & $\begin{array}{l}2.43 \\
(1.77-3.34)^{\ddagger}\end{array}$ & $\begin{array}{l}6.25 \\
(3.54-11.03)^{\neq}\end{array}$ & $\begin{array}{l}5.44 \\
(3.06-9.66)^{\neq}\end{array}$ & $\begin{array}{l}0.12 \\
(0.06-0.24)^{\neq}\end{array}$ & $\begin{array}{l}8.28 \\
(4.27-16.02)^{\neq}\end{array}$ \\
\hline Outdoors & $\begin{array}{l}5.51 \\
(3.59-8.46)^{\neq}\end{array}$ & $\begin{array}{l}5.48 \\
(3.55-8.46)^{\neq}\end{array}$ & $\begin{array}{l}4.17 \\
(3.11-5.58)^{\neq}\end{array}$ & $\begin{array}{l}3.76 \\
(2.79-5.08)^{\neq}\end{array}$ & $\begin{array}{l}8.02 \\
(4.60-13.99)^{\neq}\end{array}$ & $\begin{array}{l}6.76 \\
(3.84-11.90)^{\neq}\end{array}$ & $\begin{array}{l}1.19 \\
(0.88-1.60)\end{array}$ & $\begin{array}{l}6.67 \\
(3.43-12.98)^{\neq}\end{array}$ \\
\hline \multicolumn{9}{|l|}{ Regions } \\
\hline North & Ref. & Ref. & Ref. & Ref. & Ref. & Ref. & Ref. & Ref. \\
\hline Centre & $\begin{array}{l}0.97 \\
(0.72-1.31)\end{array}$ & $\begin{array}{l}0.66 \\
(0.44-1.00)\end{array}$ & $\begin{array}{l}1.79 \\
(1.42-2.24)^{\ddagger}\end{array}$ & $\begin{array}{l}0.88 \\
(0.65-1.20)\end{array}$ & $\begin{array}{l}1.49 \\
(1.07-2.08)^{*}\end{array}$ & $\begin{array}{l}1.91 \\
(1.09-3.35)^{\star}\end{array}$ & $\begin{array}{l}1.47 \\
(1.06-2.03)^{\star}\end{array}$ & $\begin{array}{l}1.35 \\
(0.81-2.23)\end{array}$ \\
\hline South & $\begin{array}{l}1.60 \\
(1.21-2.11)^{\neq}\end{array}$ & $\begin{array}{l}0.83 \\
(0.50-1.39)\end{array}$ & $\begin{array}{l}1.65 \\
(1.30-2.10)^{\neq}\end{array}$ & $\begin{array}{l}1.35 \\
(0.94-1.95)\end{array}$ & $\begin{array}{l}2.12 \\
(1.54-2.93)^{\ddagger}\end{array}$ & $\begin{array}{l}3.32 \\
(1.80-6.14)^{\neq}\end{array}$ & $\begin{array}{l}1.03 \\
(0.71-1.50)\end{array}$ & $\begin{array}{l}1.38 \\
(0.75-2.54)\end{array}$ \\
\hline
\end{tabular}

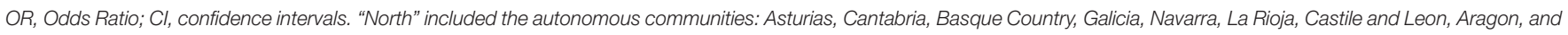

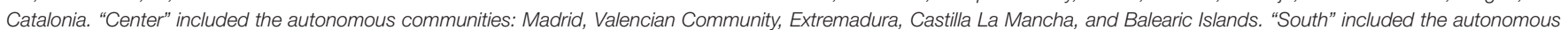

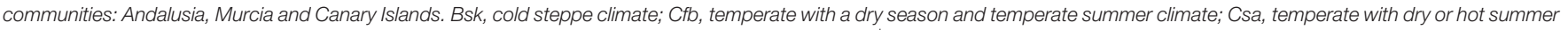
climate; Csb, temperate with dry or temperate summer climate; Subtr, subtropical climate. ${ }^{*} p<0.05 ; \neq p<0.001$; ${ }^{*}$ Reference category $=$ male.

with the presence of $L$. infantum. The indoor/outdoor habitat presented 2.43 times more risk of being infected, while the outdoor habitat presented 3.76 times more risk of infection. Regarding climate, it was observed that the $\mathrm{Cfb}, \mathrm{Csb}$, and subtropical climates reduced the presence of L. infantum when compared to the Bsk climate, being a reduction of 73,75 , and $92 \%$, respectively.

The presence of co-infections significantly increased the risk of anaplasmosis; infection by $D$. immitis increased this risk by $57 \%$ and $L$. infantum by $82 \%$. Furthermore, dogs infected by 
E. canis showed a risk of anaplasmosis 2.62 times higher. A significant association was also observed between the presence of Anaplasma spp. and the region studied. Animals in the central zone showed an increase of $91 \%$ in presenting the disease compared to those that lived in the northern zone. Those in the southern zone had 3.32 times more risk of infection than those who lived in the northern zone.

Co-infection with $L$. infantum significantly increases the risk of suffering ehrlichiosis by $59 \%$, while dogs infected with Anaplasma spp. had 2.65 times more risk of being co-infected by E. canis. No significant association was observed between the climate and the presence of Anaplasma spp. and E. canis. There was also no significant association with the region studied and the presence of dirofilariosis, leishmaniasis, and ehrlichiosis.

Although there is a relationship between the different variables and the presence of filaria and anaplasma, respectively, we must be cautious in interpreting the results because the goodness of fit of the model is not sufficient good as indicated by the Hosmer and Lemeshow test with a $p<0.05$.

\section{DISCUSSION}

This study updates the epidemiology of D. immitis, L. infantum, E. canis, and Anaplasma spp. in the Spanish geography, completing the lack of data in some autonomous communities and updating the prevalences reported in others years ago.

When the results obtained for dirofilariosis were evaluated, it was observed that the prevalences obtained in this study maintain similar values with respect to the areas that had been evaluated in the last 5-6 years, such as Barcelona, Madrid, Salamanca, or the Canary Islands $(7,8,34,35)$. However, regarding studies carried out more than 25 years ago, two phenomena can be observed: on the one hand, an increase in the prevalence in endemic areas in the south and east [i.e., Extremadura, Murcia, Valencian Community, Catalonia, Aragon; (36-40)] and, on the other hand, progressive increase in the prevalence of areas with little presence of the parasite, or very localized presence, as is the case of Galicia $(9,36,41)$, Castilla y León $(36,42)$, Castilla la Mancha $(36,43)$, or the Balearic Islands (23). Furthermore, prevalences of the parasite are reported for the first time in Asturias, Cantabria and Navarra. Only the Basque Country remains apparently free of dirofilariosis. Interestingly, a recently published work reports absence of canine dirofilariosis in northern Spain except in Navarra; although the tests used were of similar sensitivity and specificity, this difference is possibly due to the sampling method and number of samples (44). In any case, these results obtained in different studies should be interpreted with caution, due to the methodology used-sampling method, sample size and/or sensitivity, and specificity of the diagnostic test-in each of them. However, this shows the inexorable expansion of D. immitis throughout the Spanish geography as suspected, and as has already been reported at the European level (1). Curiously, there is an acute decrease in La Rioja of unknown causes (45). In general, the lowest prevalences corresponded to those autonomous communities dominated by the Cfb climate, probably due to the low temperatures that are present much of the year. These prevalences rise in La Rioja and Aragón, possibly because, despite the weather, they present important irrigated areas crossed by one of the main rivers of the Iberian Peninsula, the Ebro River.

The seropositivity toward $L$. infantum was the highest of all the vector-borne diseases analyzed and antibodies against L. infantum were detected in all the autonomous communities. The highest prevalences corresponded to the communities dominated by the Csa climate, especially those located in the east (Valencian Community, Murcia), southern Spain (Andalucía, Extremadura), and the Balearic Islands, which have been traditionally considered the endemic areas of the disease in Spain $(9,23,46)$. Here, taking as reference studies of several areas or provinces $(9,13,46-49)$, the prevalences remain high; a possible explanation being that the prophylactic measures are still insufficient. Likewise, as has been discussed previously, the different techniques and sampling carried out could be a confounding factor when comparing the variations in the prevalences obtained in the studies obtained in different years. The presence of L. infantum is confirmed throughout the north of the country, dominated by the $\mathrm{Cfb}$ climate, with the lowest seroprevalences in the entire country. Previously, except in the case of Galicia $(9,14)$ studies had been carried out in specific areas, such as towns or small areas of Cantabria, Asturias and the Basque Country, which in some cases demonstrated that leishmaniasis was already present (16), while a recent study also supports its presence in some autonomous communities in the north of the peninsula (44). The results of this research confirm not only the presence of leishmaniasis in the north, but its wide expansion throughout all the autonomous communities traditionally considered free of the disease, and, for the first time confirm its presence in some autonomous communities, such as La Rioja. In this study, the epidemiological map of the disease is completed, only studied in some provinces of the autonomous communities (i.e., Andalusia, Extremadura, Castile and Leon, Castilla la Mancha, Valencian Community, Catalonia, or Aragon) (9, 15, 17, 50-53). Furthermore, for the first time, the seroprevalence of L. infantum in the Canary Islands is estimated. These islands were considered free of the disease, although personal communications and a publication of a clinical case (54) raised suspicion of the presence of indigenous cases.

Both Anaplasma spp. and E. canis are distributed throughout the geography in a fairly homogeneous way. The presence of Anaplasma spp. may refer to A. platys or A. phagocytophilum. Although so far the latter has not been isolated in Spanish dogs, the main vector (i.e., Ixodes ricinus) is present in Spain (55), PCRpositive ticks have been found $(56,57)$ and this agent has also been isolated from other hosts, including humans (58-60). The presence of Anaplasma spp. and E. canis is quite homogeneous, without appearing to be influenced by the type of climate prevailing in the autonomous communities. This could be due to the fact that the vectors, $R$. sanguineus and I. ricinus, are widely distributed throughout the Spanish geography (61). Regarding $R$. sanguineus, this tick is the most common tick found in dogs in Spain (61-63) and it has been detected across the country, which could justify the homogeneous distribution found in this study $(61,64)$. The prevalences obtained from studies previously 
carried out in Galicia, Castilla, and Leon or Madrid on both bacteria $(9,65-68)$ were lower than the results obtained in this study, except in the case of Castilla and Leon (19.2\% for E. canis) (66). However, before considering an increase or decrease in the prevalence in these autonomous communities, the methodology used and the type of sampling should be taken into account. In any case, this demonstrates the wide presence of Anaplasma spp. and E. canis in these regions. In addition, other previous studies have published seroprevalence data that were mostly reported in localized areas or provinces of the autonomous communities of Asturias, Aragon, Catalonia, Andalusia, the Valencian Community or the Balearic Islands (9, 23, 69); furthermore, a recent study reported presence of these diseases in the north of Spain, but showing lower prevalences, which could be due to the different sampling procedures-being the samples from the northernmost area of the studied autonomous communities-and number of samples (44). The results of this research have made it possible to complete and update the epidemiological map of these autonomous communities, as well as to provide prevalences in those communities that had never been epidemiologically evaluated.

Only significant differences were observed by gender in Dirofilaria infections; although other epidemiological studies found no significant differences $(9,14,34)$, these differences were also observed in others $(7,8,70)$. Regarding age, higher seropositivities were found in adult dogs between 1 and 10 years, observing a slight decrease in dogs $>15$ years. In all cases, the prevalences were lower in dogs $<1$ year, possibly due to less exposure to the pathogens and, in the case of D. immitis, due to the fact that antigens are not detected until 6 months post-infection. Previous epidemiological studies have obtained different results when the dogs were assessed by age, finding statistical significance between age groups in some epidemiological studies of vector-borne diseases but not in others $(8,9,46)$. This could be due to the different methodology used in the studies, both in sampling and in the sensitivity/specificity of the different tests used.

By habitat, prevalences were significantly lower in dogs living indoors. This agrees with previous studies carried out in vectorborne diseases $(9,23,34)$. This result is understandable since indoor animals are more protected against the presence of vectors. However, the results also show that this group of animals is at risk of infection, so prophylactic measures should be applied equally.

Co-infections were observed in $15 \%$ of the dogs; it has been previously reported that co-infections of vector-borne diseases are common, and studies have reported that up to half of all patients with positive test results for vector-borne diseases may have evidence of co-infection or co-exposure (71-74). Furthermore, the results showed that having some of the vectorborne infections studied increased the risk of showing other co-infections (i.e., Dirofilaria and Anaplasma; Leishmania and Ehrlichia; Leishmania, and Anaplasma). This highlights a lack of preventive measures to avoid the interaction with the vectors, and the need of the implementation of awareness campaigns among veterinarians and owners. The efficacy of the preventive measures against $D$. immitis has been observed in Gran Canaria with a constant decrease of the prevalences across 15 years $(8,70,75)$.
In the case of $D$. immitis, the detection of parasitic antigens allows to determine current infections. However, the detection of antibodies that occur in the case of Leishmania, Ehrlichia and Anaplasma indicates exposure to disease-causing organisms, but the presence of antibodies does not always indicate disease, which, in some cases, may be confirmed by molecular techniques $(3,12)$. In any case, the presence of antibodies denotes that, whether or not it is a current infection, the animal is exposed to the disease and, therefore, at risk of infection, which is why preventive measures are necessary either way. On the other hand, absence of antibodies can also be found in infected animals confirmed by other techniques, such as PCR (76). Furthermore, some treated dogs might remain as reservoirs of vector-borne diseases. Therefore, even dogs that have been treated should be screened yearly for the presence of disease (77).

This study has a number of limitations. First, even though the samples were chosen randomly by veterinary clinicians, there is a possibility that they have inadvertently selected the samples out of some sort of personal preference. Likewise, it must be taken into account that the sample collected is not representative of each Autonomous Community, especially in those of great extension, despite the fact that efforts have been made to recruit the maximum number of veterinary clinics from different points of geography.

The results show a wide distribution of the vector-borne diseases studied; therefore, awareness of these diseases should be raised among the veterinary clinicians and dog owners, and prophylactic plans and measures should be implemented routinely. This is especially important in the vector-borne diseases studied in the present research, because all they are characterized by a wide range of symptoms, highlighting the presence of non-specific clinical signs or clinical-pathological anomalies that can lead to misdiagnosis. Also, many of these animals remain asymptomatic, being uncontrolled reservoirs of the infection; moreover, it has been described that animals with subclinical infections present an increased risk of disease transmission (78). In addition, we must consider the important zoonotic potential of the diseases studied, as the presence of human infections or risk of infection has already been described $(5,24,25,28)$. In this sense, it is essential to carry out a close collaboration between veterinarians, physicians and health authorities that allow, under the concept of One Health, to carry out a more rigorous and effective control of these diseases.

\section{DATA AVAILABILITY STATEMENT}

The raw data supporting the conclusions of this article will be made available by the authors, without undue reservation.

\section{ETHICS STATEMENT}

This animal study was reviewed and approved by ethical committee of Veterinary Medicine Service of the University of Las Palmas de Gran Canaria. Written informed consent was obtained from the owners for the participation of their animals in this study. 


\section{AUTHOR CONTRIBUTIONS}

EC, RM and JM-A designed the study and wrote the manuscript. RM, NC-R, JM, and YF-C performed the fieldwork and collected the data. All authors participated in the discussion of the results, corrected, and read and approved the final manuscript.

\section{FUNDING}

This research was supported by Agencia Canaria de Investigación, Innovación y Sociedad de la Información, Gobierno de Canarias (ProID2017010111) and Ministerio de Ciencia, innovación y Universidades. Gobierno de España

\section{REFERENCES}

1. Morchón R, Carretón E, González-Miguel J, Mellado-Hernández I. Heartworm disease (Dirofilaria immitis) and their vectors in Europe - new distribution trends. Front Physiol. (2012) 3:196. doi: 10.3389/fphys.2012.00196

2. Dantas-Torres F. Climate change, biodiversity, ticks and tick-borne diseases: the butterfly effect. Int J Parasitol Parasites Wildl. (2015) 4:45261. doi: 10.1016/j.ijppaw.2015.07.001

3. Sainz Á, Roura X, Miró G, Estrada-Peña A, Kohn B, Harrus S, et al. Guideline for veterinary practitioners on canine ehrlichiosis and anaplasmosis in Europe. Parasit Vectors. (2015) 8:75. doi: 10.1186/s13071-015-0649-0

4. Miró G, Cardoso L, Pennisi MG, Oliva G. Canine Leishmaniosis: new concepts and ideas about an expanding zoonosis: part two. Parasitol Trends. (2008) 24:371-7. doi: 10.1016/j.pt.2008.05.003

5. Simón F, Siles-Lucas M, Morchón R, González-Miguel J, Mellado I, Carretón E, et al. Human and animal dirofilariasis: the emergence of a zoonotic mosaic. Clin Microbiol Rev. (2012) 25:507-44. doi: 10.1128/CMR.00012-12

6. Simón L, Afonin A, López-Díez LI, González-Miguel J, Morchón R, Carretón E, et al. Geo-environmental model for the prediction of potential transmission risk of Dirofilaria in an area with dry climate and extensive irrigated crops. The case of Spain. Vet Parasitol. (2014) 200:25764. doi: 10.1016/j.vetpar.2013.12.027

7. Montoya-Alonso JA, Carretón E, Simón L, González-Miguel J, García-Guasch L, Morchón R, et al. Prevalence of Dirofilaria immitis in dogs from Barcelona: validation of a geospatial prediction model. Vet Parasitol. (2015) 212:4569. doi: 10.1016/j.vetpar.2015.06.025

8. Montoya-Alonso JA, Carretón E, Morchón R, Silveira-Viera L, Falcón Y, Simón F. The impact of the climate on the epidemiology of Dirofilaria immitis in the pet population of the Canary Islands. Vet Parasitol. (2016) 216:66-71. doi: 10.1016/j.vetpar.2015.12.005

9. Miró G, Montoya A, Roura X, Gálvez R, Sainz, A. Seropositivity rates for agents of canine vector-borne diseases in Spain: a multicentre study. Parasit Vectors. (2013) 6:117. doi: 10.1186/1756-3305-6-117

10. Paltrinieri S, Gradoni L, Roura X, Zatelli A, Zini E. Laboratory tests for diagnosing and monitoring canine leishmaniasis. Vet Clin Pathol. (2016) 45:552-78. doi: 10.1111/vcp.12413

11. Solano-Gallego L, Di Filippo L, Ordeix L, Planellas M, Roura X, Altet L, et al. Early reduction of specific antibodies against Leishmania infantum and parasitaemia in blood during treatment in dogs with moderate or severe disease. Parasit Vectors. (2016) 9:235. doi: 10.1186/s13071-016-1519-0

12. Solano-Gallego L, Miró G, Koutinas A, Cardoso L, Pennisi MG, Ferrer L, et al. LeishVet guidelines for the practical management of canine leishmaniasis. Parasit Vectors. (2011) 20:86. doi: 10.1186/1756-3305-4-86

13. Morillas F, Sanchez Rabasco F, Ocaña J, Martin-Sanchez J, Ocaña-Wihelmi J, Acedo C. Leishmaniasis in the focus of the Axarquía region, province of Málaga, southern Spain: a survey of humans, dogs, and vector. Parasitol Res. (1996) 82:569-70. doi: 10.1007/s004360050164

14. Amusátegui I, Sainz A, Aguirre E, Tesouro MA. Seroprevalence of Leishmania infantum in northwestern Spain, an area traditionally
(GOB-ESP2019-12). Boehringer Ingelheim Spain has also partially contributed to the financing of this study. The funder was not involved in the study design, collection, analysis, interpretation of data, the writing of this article or the decision to submit it for publication.

\section{ACKNOWLEDGMENTS}

The authors would like to thank all veterinarians who kindly collaborated and provided samples for this research. Without their collaboration and dedication this study could not have been carried out. Also, they would like to thank Uranovet for their help and support throughout all the study. considered free of leishmaniasis. Ann N $\quad Y$ Acad Sci. (2004) 1026:154-7. doi: 10.1196/annals.1307.022

15. Ballart C, Alcover MM, Portús M, Gállego M. Is leishmaniasis widespread in Spain? First data on canine leishmaniasis in the province of Lleida, Catalonia, northeast Spain. Trans R Soc Trop Med Hyg. (2012) 106:1346. doi: 10.1016/j.trstmh.2011.11.001

16. Miró G, Checa R, Montoya A, Hernández L, Dado D. Current status of Leishmania infantum infection in shelter dogs in northern Spain. Parasit Vectors. (2012) 5:60. doi: 10.1186/1756-3305-5-60

17. Ballart C, Alcover MM, Picado A, Nieto J, Castillejo S, Portús M, et al. First survey on canine leishmaniasis in a non-classical area of the disease in Spain (Lleida, Catalonia) based on a veterinary questionnaire and a cross-sectional study. Prev Vet Med. (2013) 109:116-27. doi: 10.1016/j.prevetmed.2012. 09.003

18. Mattin MJ, Solano-Gallego L, Dhollander S, Afonso A, Brodbelt DC. The frequency and distribution of canine leishmaniosis diagnosed by veterinary practitioners in Europe. Vet J. (2014) 200:410-9. doi: 10.1016/j.tvjl.2014.03.033

19. Jaenson TG, Jaenson DG, Eisen L, Petersson E. Changes in the geographic distribution and abundance of the Ixodes ricinus tick during the last 30 years in Sweden. Parasit Vectors. (2012) 5:8. doi: 10.1186/1756-3305-5-8

20. Dantas-Torres F. Biology and ecology of the brown dog tick, Rhipicephalus sanguineus. Parasit Vectors. (2010) 3:26. doi: 10.1186/1756-3305-3-26

21. Harrus S, Waner T. Review diagnosis of canine monocytotropic ehrlichiosis (Ehrlichia canis): an overview. Vet J. (2011) 187:2926. doi: 10.1016/j.tvjl.2010.02.001

22. Harrus S. Perspectives on the pathogenesis and treatment of canine monocytic ehrlichiosis (Ehrlichia canis). Vet J. (2015) 204:239-40. doi: 10.1016/j.tvjl.2015.04.027

23. Solano-Gallego L, Llull J, Osso M, Hegarty B, Breitschwerdt E. A serological study of exposure to arthropod-borne pathogens in dogs from northeastern Spain. Vet Res. (2006) 37:231-44. doi: 10.1051/vetres:2005054

24. Maeda K, Markowitz N, Hawley RC, Ristic M, Cox D, McDade JE. Human infection with Ehrlichia Canis, a Leukocytic Rickettsia. N Engl J Med. (1987) 316:853-6. doi: 10.1056/NEJM198704023161406

25. Nicholson WL, Allen KE, McQuiston JH, Breitschwerdt EB, Little SE. The increasing recognition of rickettsial pathogens in dogs and people. Trends Parasitol. (2010) 26:205-12. doi: 10.1016/j.pt.2010.01.007

26. Stuen S, Granquist EG, Silaghi C. Anaplasma phagocytophilum-a widespread multi-host pathogen with highly adaptive strategies. Front Cell Infect Microbiol. (2013) 3:31. doi: 10.3389/fcimb.2013.00031

27. Arraga-Alvarado CM, Qurollo BA, Parra OC, Berrueta MA, Hegarty BC, Breitschwerdt EB. Case report: molecular evidence of Anaplasma platys infection in two women from Venezuela. Am J Trop Med Hyg. (2014) 91:11615. doi: 10.4269/ajtmh.14-0372

28. Alvar J, Vélez ID, Bern C, Herrero M, Desjeux P, Cano J, et al. The WHO Leishmaniasis control Team. Leishmaniasis Worldwide and global estimates of its incidence. PLoS ONE. (2012) 7:e35671. doi: 10.1371/journal.pone. 0035671 
29. Beugnet F, Marié JL. Emerging arthropod-borne diseases of companion animals in Europe. Vet Parasitol. (2009) 163:298305. doi: 10.1016/j.vetpar.2009.03.028

30. Genchi C, Mortarino M, Rinaldi L, Cringoli G, Traldi G, Genchi M. Changing climate and changing vector-borne disease distribution: the example of Dirofilaria in Europe. Vet Parasitol. (2011) 176:2959. doi: 10.1016/j.vetpar.2011.01.012

31. Maia C, Cardoso L. Spread of Leishmania infantum in Europe with dog travelling. Vet Parasitol. (2015) 213:2-11. doi: 10.1016/j.vetpar.2015.05.003

32. Agencia Estatal de Meteorología, Ministerio de Agricultura, Alimentación y Medio Ambiente. In: Climate Atlas of the Archipelagos of the Canary Islands, Madeira and the Azores. (2012). Available online at: https://www.ipma.pt/ export/sites/ipma/bin/docs/publicacoes/atlas.clima.ilhas.iberico.2011.pdf (accessed 20 May 2020).

33. Agencia Estatal de Meteorología, Ministerio de Agricultura, Alimentación y Medio Ambiente. In: Iberian Climate Atlas. Air temperature and precipitation (1971-2000). (2011). https://www.aemet.es/documentos/es/conocermas/ publicaciones/Atlas-climatologico/Atlas.pdf (accessed 20 May 2020).

34. Montoya-Alonso JA, Morchón R, Falcón-Cordón Y, Falcón-Cordón S, Simón F, Carretón E. Prevalence of heartworm in dogs and cats of Madrid, Spain. Parasit Vectors. (2017) 10:354. doi: 10.1186/s13071-017-2299-x

35. Diosdado A, Gómez PJ, González-Miguel J, Simón F, Morchón R. Current status of canine dirofilariosis in an endemic area of western Spain. $J$ Helminthol. (2018) 92:520-3. doi: 10.1017/S0022149X17000591

36. Guerrero J, Rojo F, Ródenas A. Estudio de la incidencia de la enfermedad del gusano del corazón en la población canina española. Med Vet. (1989) 6:217-20.

37. Guerrero J, Rodenas A, Gutierrez Galindo J, Florit F. The extension of the prevalence of Dirofilaria immitis in Cataluña, Spain. In: MD Soll, DH Knigh, editors. Proceedings of the Heartworm Symposium '95. Batavia, IL: American Heartworm Society (1995) p. 73-7.

38. Gutiérrez J, Guerrero J, Ródenas A, Castella J, Muñoz E, Ferrer D, et al. Evolución de Dirofilaria immitis en Cataluña. Med Vet. (1995) 12:10.

39. Ortega-Mora LM, Gómez-Bautista M, Rojo-Vázquez F, Rodenas A, Guerrero JA. Survey of the prevalence of canine filariasis in Spain. Prevent Vet Med. (1991) 11:63-8. doi: 10.1016/S0167-5877(05)80045-5

40. Rojo-Vázquez FA, Valcárcel F, Guerrero J, Gómez, M. Prevalencia de la dirofilariosis canina en cuatro áreas geográficas de España. Med Vet. (1990) 7:297-305.

41. Simón F, Morchón R, González J. Dirofilariosis canina en La Coruña. Argos. (2009) 106:10-2.

42. Pérez R, Goméz M, Encinas A. Canine filariasis in Salamanca (northwest Spain). Ann Trop Med Parasitol. (1989) 83:14350. doi: 10.1080/00034983.1989.11812322

43. Gómez-Bautista M, Ortega-Mora LM. Es la dirofilariosis una enfermedad frecuente en España? Argos. (2002) 39:50. Available online at: https:// www.portalveterinaria.com/articoli/articulos/26822/estatus-actual-de-ladistribucion-de-la-dirofilariosis-animal-y-humana-en-espana-y-portugal. html

44. Díaz-Regañón D, Roura X, Suárez ML, León M, Sainz Á. Serological evaluation of selected vector-borne pathogens in owned dogs from northern Spain based on a multicenter study using a commercial test. Parasit Vect. (2020) 13:301. doi: 10.1186/s13071-020-04172-5

45. Morchón R, Moya I, González-Miguel J, Montoya MN, Simón F. Zoonotic Dirofilaria immitis infections in a province of Northern Spain. Epidemiol Infect. (2010) 138:380-3. doi: 10.1017/S0950268809990434

46. Martín-Sánchez J, Morales-Yuste M, Acedo-Sánchez C, Barón S, Díaz V. Canine leishmaniasis in southeastern Spain. Emerg Infect Dis. (2009) 15:7958. doi: 10.3201/eid1505.080969

47. Gálvez R, Miró G, Descalzo MA, Nieto J, Dado D, Martín O, et al. Emerging trends in the seroprevalence of canine Leishmaniasis in the Madrid region (Central Spain). Vet Parasitol. (2010) 69:327-34. doi: 10.1016/j.vetpar.2009.11.025

48. Amela C, Mendez I, Torcal JM, Medina G, Pachón I, Cañavate C, et al. Epidemiology of canine leishmaniasis in the Madrid region, Spain. Eur J Epidemiol. (1995) 11:157-61. doi: 10.1007/BF01719481

49. Millán J, Zanet S, Gomis M, Trisciuoglio A, Negre N, Ferroglio E. An investigation into alternative reservoirs of canine leishmaniasis on the endemic island of Mallorca (Spain). Transbound Emerg Dis. (2011) 58:3527. doi: 10.1111/j.1865-1682.2011.01212.x

50. Encinas Grandes A, Gómez Bautista M, Martin Novo M, Simon Martin F. Leishmaniasis in the province of Salamanca, Spain. Prevalence in dogs, and seasonal dynamics of vectors. Ann Parasitol Hum Comp. (1988) 63:387-97. doi: 10.1051/parasite/1988 636387

51. Fisa R, Gállego M, Castillejo S, Aisa MJ, Serra T, Riera C, et al. Epidemiology of canine leishmaniosis in Catalonia (Spain) the example of the Priorat focus. Vet Parasitol. (1999) 83:87-97. doi: 10.1016/S0304-4017(99)00074-6

52. Martinez Cruz MS, Martinez Moreno A, Martinez Moreno FJ, Martinez Gómez F, Hernández Rodriguez S. Epidemiología de la leishmaniosis canina en Córdoba. Rev Ibér Parasitol. (1990) 50:1-7.

53. Velez R, Ballart C, Domenech E, Abras A, Fernández-Arévalo A, Gómez $\mathrm{SA}$, et al. Seroprevalence of canine Leishmania infantum infection in the Mediterranean region and identification of risk factors: the example of North-Eastern and Pyrenean areas of Spain. Prev Vet Med. (2019) 162:6775. doi: 10.1016/j.prevetmed.2018.10.015

54. Dandrieux JRS, Sacchini F, Harms G, Globokar M, Balzer HJ, Pantchev $\mathrm{N}$. Canine Leishmania infantum infection: an imported case in UK after staying in the Canary Islands. Parasitol Res. (2018) 117:3314. doi: $10.1007 / \mathrm{s} 00436-017-5681-\mathrm{x}$

55. Márquez-Jiménez FJ, Hidalgo-Pontiveros A, Contreras-Chova F, RodríguezLiébana JJ, Muniain-Ezcurra MA. [Ticks (Acarina: Ixodidae) as vectors and reservoirs of pathogen microorganisms in Spain] Enferm Infecc Microbiol Clin. (2005) 23:94-102. doi: 10.1157/13071613

56. Barandika JF, Hurtado A, García-Sanmartín J, Juste RA, Anda P, GarcíaPérez AL. Prevalence of tick-borne zoonotic bacteria in questing adult ticks from northern Spain. Vector Borne Zoonotic Dis. (2008) 8:82935. doi: $10.1089 / \mathrm{vbz} .2008 .0023$

57. Portillo A, Pérez-Martínez L, Santibáñez S, Santibáñez P, Palomar AM, Oteo JA. Anaplasma spp. in wild mammals and Ixodes ricinus from the north of Spain. Vector Borne Zoonotic Dis. (2011) 11:3-8. doi: 10.1089/vbz.2009.0214

58. Gray JS, Dautel H, Estrada-Pena A, Kahl O, Lindgren E. Effects of climate change on ticks and tick-borne diseases in Europe. Interdiscip Perspect Infect Dis. (2009) 2009:593232. doi: 10.1155/2009/593232

59. Medlock JM, Hansford KM, Bormane A, Derdakova M, EstradaPeña A, George JC, et al. Driving forces for changes in geographical distribution of Ixodes ricinus ticks in Europe. Parasit Vect. (2013) 6:1. doi: 10.1186/1756-3305-6-1

60. Oteo JA, Blanco JR, Martínez de Artola V, Ibarra V. First report of human granulocytic ehrlichiosis from southern Europe (Spain). Emerg Infect Dis. (2000) 6:430-2. doi: 10.3201/eid0604.000425

61. Estrada-Peña A, Roura X, Sainz A, Miró G, Solano-Gallego L. Species of ticks and carried pathogens in owned dogs in Spain: results of a one-year national survey. Ticks Tick Borne Dis. (2017) 8:443-52. doi: 10.1016/j.ttbdis.2017.02.001

62. Chitimia-Dobler L, Kurzrock L, Molčányi T, Rieß R, Mackenstedt U, Nava S. Genetic analysis of Rhipicephalus sanguineus sensu lato ticks, parasites of dogs in the Canary Islands, Cyprus, and Croatia, based on mitochondrial 16S rRNA gene sequences. Parasitol Res. (2019) 118:106771. doi: 10.1007/s00436-019-06214-z

63. Vila A, Estrada-Peña A, Altet L, Cusco A, Dandreano S, Francino O, et al. Endosymbionts carried by ticks feeding on dogs in Spain. Ticks Tick Borne Dis. (2019) 10:848-52. doi: 10.1016/j.ttbdis.2019.04.003

64. European Centre for Disease Prevention and Control Tick species Distribution maps (2019) Available online at: https://www.ecdc.europa. $\mathrm{eu} / \mathrm{en} /$ disease-vectors/surveillance- and-disease-data/tick-maps (accessed 20 May 2020).

65. Couto CG, Lorentzen L, Beall MJ, Shields J, Bertolone N, Couto JI, et al. Serological study of certain vector-borne diseases in refuge dogs in central Spain. Vector by Zoonotic Dis. (2010) 10:885-8. doi: 10.1089/vbz.2009.0063

66. Sainz A, Amusátegui I, Tesouro MA. Canine ehrlichiosis in the community of Madrid in central Spain. Ann NY Acad Sci. (1998) 849:438-40. doi: 10.1111/j.1749-6632.1998.tb11091.x

67. Sainz A, Delgado S, Amusátegui I, Tesouro MA. Seroprevalence of canine ehrlichiosis in Castilla-León (northwest of Spain). Prev Med Vet. (1996) 29:1-7. doi: 10.1016/S0167-5877(96)01060-4 
68. Sainz A, Tesouro MA, Rodriguez F, Mayoral I, Mazzucchelli F. Seroprevalence of Ehrlichia canis infections in police dogs in Spain. Prev Vet Med. (1995) 23:179-82. doi: 10.1016/0167-5877(94)00440-T

69. Amusátegui I, Tesouro MA, Kakoma I, Sainz A. Serological reactivity to Ehrlichia canis, Anaplasma phagocytophilum, Neorickettsia risticii, borrelia Burgdorferi and Rickettsia conorii in dogs from northwestern Spain. Vector Borne Zoonotic Dis. (2008) 8:797-803. doi: 10.1089/vbz.20 07.0277

70. Montoya-Alonso JA, Carretón E, Corbera JA, Juste MC, Mellado I, Morchón $\mathrm{R}$, et al. Current prevalence of Dirofilaria immitis in dogs, cats and humans from the island of Gran Canaria, Spain. Vet Parasitol. (2011) 176:2914. doi: 10.1016/j.vetpar.2011.01.011

71. Tabar MD, Altet L, Martínez V, Roura X. Wolbachia, filariae and Leishmania coinfection in dogs from a Mediterranean area. J Small Anim Pract. (2013) 54:174-8. doi: 10.1111/jsap.12041

72. Maggi RG, Birkenheuer AJ, Hegarty BC, Bradley JM, Levy MG. Comparison of serological and molecular panels for the diagnosis of vector-borne diseases in dogs. Parasit Vect. (2014) 7:127. doi: 10.1186/1756-3305-7-127

73. Attipa C, Solano-Gallego L, Papasouliotis K, Soutter F, Morris D, Helps C, et al. Association between canine leishmaniosis and Ehrlichia canis co-infection: a prospective case-control study. Parasit Vectors. (2018) 11:184. doi: 10.1186/s13071-018-2717-8

74. Baxarias M, Álvarez-Fernández A, Martínez-Orellana $\mathrm{P}$, Montserrat-Sangrà S, Ordeix L, Rojas A, et al. Does co-infection with vector-borne pathogens play a role in clinical canine leishmaniosis? Parasit Vectors. (2018) 11:135. doi: 10.1186/s13071-018-2724-9

75. Montoya-Alonso JA, Carretón E, Juste MC, Mellado I, Morchón R, Simón F. Epidemiological survey of canine heartworm disease on the island of Gran
Canaria (Canary Islands - Spain) between 2000 and 2008. Vet Parasitol. (2010) 173:165-8. doi: 10.1016/j.vetpar.2010.06.008

76. Iniesta L, Fernández-Barredo S, Bulle B, Gómez MT, Piarroux R, Gállego M, et al. Diagnostic techniques to detect cryptic leishmaniasis in dogs. Clin Diagn Lab Immunol. (2002) 9:1137-41. doi: 10.1128/CDLI.9.5.1137-1141.2002

77. Schaefer JJ, Needham GR, Bremer WG. Tick acquisition of Ehrlichia canis from dogs treated with doxycycline hyclate. Antimicrob Agents Chemother. (2007) 51:3394-6. doi: 10.1128/AAC.00358-07

78. Baneth G, Bourdeau P, Bourdoiseau G, Bowman D, Breitschwerdt E, Capelli G et al. Vector-borne diseases-constant challenge for practicing veterinarians: recommendations from the CVBD World forum. Parasit Vectors. (2012) 5:55. doi: 10.1186/1756-3305-5-55

Conflict of Interest: Although the article has been partially financed by Boehringer Ingelheim Spain, none of the authors maintains a contractual relationship with the company.

The authors declare that the research was conducted in the absence of any commercial or financial relationships that could be construed as a potential conflict of interest.

Copyright (C) 2020 Montoya-Alonso, Morchón, Costa-Rodríguez, Matos, FalcónCordón and Carretón. This is an open-access article distributed under the terms of the Creative Commons Attribution License (CC BY). The use, distribution or reproduction in other forums is permitted, provided the original author(s) and the copyright owner(s) are credited and that the original publication in this journal is cited, in accordance with accepted academic practice. No use, distribution or reproduction is permitted which does not comply with these terms. 